\title{
Percutaneous endoscopic cervical discectomy: 16 years of experience and literature review
}

\author{
Discectomia endoscópica percutânea cervical: 16 anos de \\ experiência e revisão da literatura
}

\section{Discectomía endoscópica percutánea cervical: 16 años de experiência y revisión de la literatura}

\author{
Gun Choi ${ }^{1}$ \\ Sang Ho Lee ${ }^{1}$ \\ Max Franco de Carvalho' \\ Nicolas Prada ${ }^{2}$
}

\begin{abstract}
The advancement of the percutaneous endoscopic lumbar discectomy (PECD) and its clinical success have led to similar minimally invasive approaches to the cervical spine. The goal of PECD is the decompression of the cervical nerve root through a direct endoscopic visualization, removing the herniated mass and shrinking the nucleous pulposus with the use of microforceps and holmium: yttrium-aluminum-garnet (Ho:YAG) laser. The senior author have performed PECD with cervical laser assisted endoscopy since 1993. The PECD is indicate to patients with constrained or unconstrained soft herniated cervical disc, positive provocative test, and no bony spur larger than $2 \mathrm{~mm}$, regardless of the herniation size. The authors described the surgical technique of PECD and report their 16 years of experience in the endoscopic treatment of the herniated cervical disc.
\end{abstract}

\section{RESUMO}

$\mathrm{O}$ avanço da discectomia endoscópica percutânea lombar e seu sucesso clínico levaram a abordagens minimamente invasivas para a coluna cervical. O objetivo da discectomia endoscópica percutânea cervical é o de descomprimir a raiz do nervo cervical por meio de uma visualização endoscópica direta, eliminando o fragmento herniado e diminuindo o núcleo pulposo, com o uso de fórceps e micro Hólmio: ítrio-alumínio-granada (Ho:YAG) laser. A discectomia endoscópica percutânea cervical com laser tem sido utilizada desde 1993 e é indicada nos pacientes com hérnia de disco, contida ou não, teste provocativo positivo e ausência de osteófito maior que $2 \mathrm{~mm}$, independentemente do tamanho da hérnia. Os autores descreveram a técnica cirúrgica de discectomia endoscópica percutânea cervical e relataram 16 anos de experiência no tratamento endoscópico do disco cervical herniado.

\section{RESUMEN}

El avance en la discectomía endoscópica percutánea lumbar y su triunfo clínico llevaron a abordajes mínimamente invasivos en la columna cervical. El objetivo de la discectomía endoscópica percutánea cervical es descomprimir la raíz del nervio cervical, por una visualización endoscópica directa, eliminando el fragmento herniado y disminuyendo el núcleo pulposo, con el uso de fórceps y micro Holmio: itrio-aluminio-granada (Ho:YAG) laser. La discectomía endoscópica percutánea cervical con laser ha sido utilizada desde 1993. Esta es indicada en pacientes con hernia discal contenida o no, test provocativo positivo, ausencia de osteofitos mayores que $2 \mathrm{~mm}$, independientemente del tamaño de la hernia. Los autores describen la técnica quirúrgica de discectomía endoscópica percutánea cervical y relatan 16 años de experiencia en el tratamiento endoscópico de disco cervical herniado.

\footnotetext{
Study carried out at Wooridul Spine Hospital - Seoul, South Korea.

'MD PhD, Department of Neurosurgery of Wooridul Spine Hospital - Seoul, South Korea.

${ }^{2} \mathrm{MD}$, Departament of Neurosurgery of Wooridul Spine Hospital - Seoul, South Korea. 
KEYWORDS: Diskectomy, percutaneous/methods; Surgical procedures, minimally invasive/ methods; Intervertebral disk displacement/surgery; Endoscopy
DESCRITORES: Discotomia percutânea/métodos; Procedimentos cirúrgicos minimamente invasivos/ métodos; Deslocamento do disco intervertebral/cirurgia; Endoscopia
DESCRIPTORES: Discectomía

percutánea/métodos; Procedimientos quirúrgicos mínimamente invasivos/ métodos; Desplazamiento del disco intervertebral/cirurgía; Endoscopía

\section{INTRODUCTION}

Over the past decade, the percutaneous endoscopic cervical discectomy (PECD) of the lumbar spine has been widely used to treat lumbar soft disc herniation. The improvement of this technology and its clinical sucess have led to similar minimally invasive approaches to the cervical spine $^{1-3}$. These percutaneous approaches preserve healthy tissues, decrease operative complications rates, faster recovery and shorter hospitalization ${ }^{4}$. The PECD should be considered as an alternative to the standard anterior cervical discectomy and fusion, the artificial disc replacement and the posterior microdiscectomy in the treatment of soft cervical disc herniation ${ }^{5}$.

In late reports, the main goal of the intradiscal percutaneous cervical procedure was the center of the disc, and the clinical application was limited ${ }^{6}$. After the first description of cervical percutaneous discectomy by Tajima et $\mathrm{al}^{7}$, the use of chemonucleolysis with chymopapain ${ }^{8-10}$, automated percutaneous cervical discectomy $y^{8-10}$ and laser percutaneous cervical decompression have been described in the literature ${ }^{11,12}$.

The goal of PECD is to decompress the cervical nerve root through a direct endoscopic visualization, removing the herniated mass and shrinking the nucleous pulposus with the use of microforceps and holmium: yttrium-aluminum-garnet (Ho:YAG) laser ${ }^{11,12}$. The senior author has performed PECD with cervical laser assisted endoscopy since 1993 in the Wooridul Spine Hospital (WHS). The cervical working channel endoscope developed in 2002 (WSH endoscopy set ${ }^{\circledR}$, Storz, Germany) is an advanced form of the cervical endoscope, which is currently used for percutaneous endoscopic cervical discectomy ${ }^{13}$.

\section{INDICATIONS AND CONTRAINDICATIONS OF PECD}

PECD is indicated in the surgical treatment of soft cervical disc herniation confirmed by magnetic resonance imaging (MRI) or computed tomography (CT) with failed cervicobrachialgia conservative treatment for at least six weeks. The best indication is patients with a positive provocative test, no bony spur larger than $2 \mathrm{~mm}$, preserving disc height regardless of the herniation size, location (central, lateral and foraminal) or epidural leakage ${ }^{2,13}$. According to the senior author's previous series complain of cervicobrachialgia and lateral localization of the herniated disc are the two most predicting factors concerning excellent long term results.

A very bulky herniation is not a contraindication if the patient has no myelopathic symptoms and signs.

PECD is contraindicated in patients presenting a severe neurologic deficit, segmental instability, acute pyramidal syndrome, progressive myelopathy, previous same segment surgery, migrated discs, calcified disc protrusion, disc space less than $3 \mathrm{~mm}$, ossification of the posterior longitudinal ligament ${ }^{2,14}$.

\section{SURGICAL TECHNIQUE} Instruments and equipments

Recently, WSH (Korea), in collaboration with Storz (Germany), developed a large working channel endoscope for the cervical spine (Figure 1).

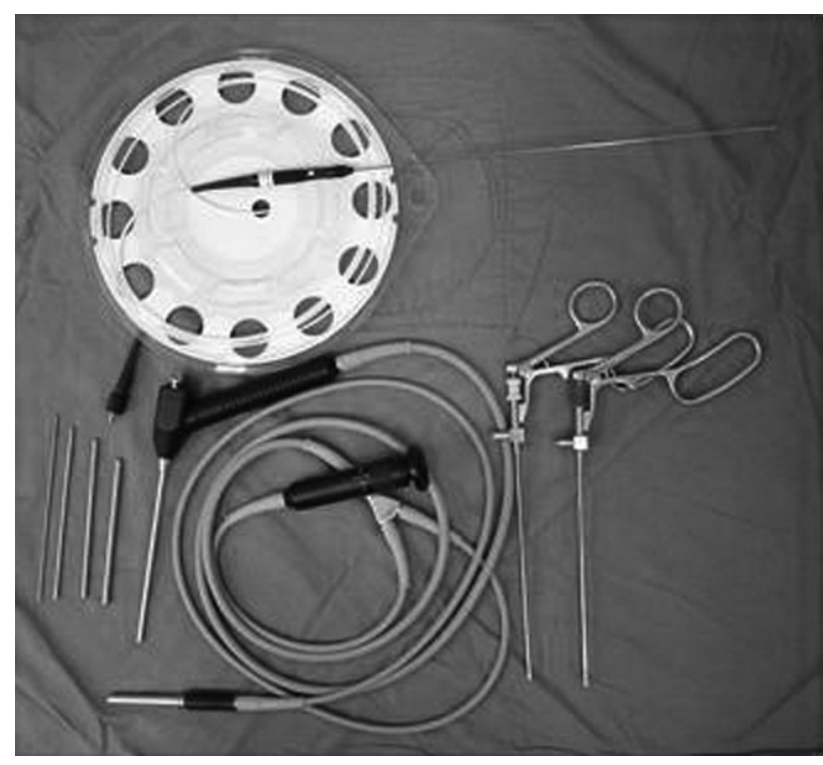

Figure 1

WSH cervical endoscopy set (Karl Storz, Germany)

The cervical endoscope differs from the lumbar endoscope in the following ways:

- it is $0^{\circ}$ endoscope i.e. the lens is not angled. This is because the endoscope which is inserted from the anterior margin of the disc and, then, advanced to the posterior margin provides an "end on" view of the pathology;

- it is smaller in size. The working length is $120 \mathrm{~mm}$ and the outer diameter is $4 \mathrm{~mm}$; 

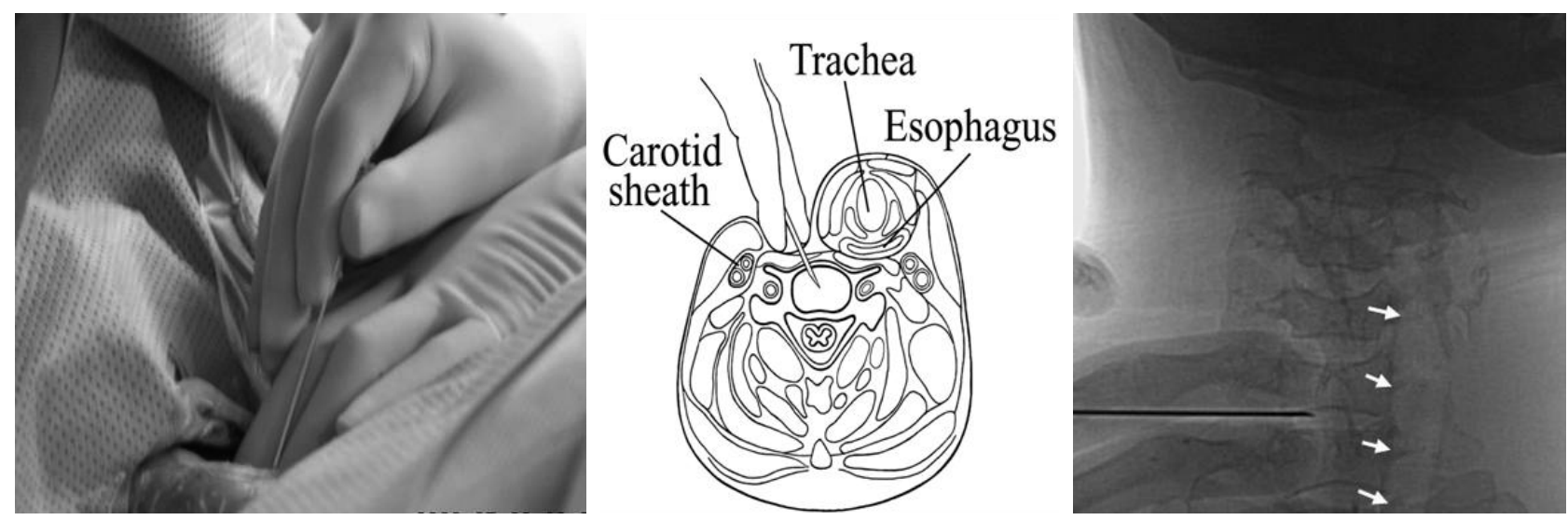

Figure 2

Needle puncture of the cervical disc and AP cervical spine radiograph showing the trachea mobilization

- the central working channel has a diameter of 1.9 $\mathrm{mm}$, which allows the passage of a microforceps of 1.5 $\mathrm{mm}$ and laser probe of $1 \mathrm{~mm}$. There are two separate channels for suction and irrigation. The eyepiece has an integrated light connection remote from the instrument.

The WSH recommended endoscopy set for PECD consists of (Figure 1):

- 18 gauge needle of $88 \mathrm{~mm}$ length;

- K-wire guide: $1.8 \mathrm{~mm}$ diameter and $250 \mathrm{~mm}$ length;

- annular cutter;

- cervical sequential dilator: $180 \mathrm{~mm}$ long and $2 \mathrm{~mm}$ diameter, $150 \mathrm{~mm}$ long and $4 \mathrm{~mm}$ diameter;

- cervical obturator: $4 \mathrm{~mm}$ diameter and $120 \mathrm{~mm}$ length;

- working cannula: $5 \mathrm{~mm}$ diameter and $100 \mathrm{~mm}$ length;

- fluoroscopic forceps;

- microforceps: double action jaws with $1.7 \mathrm{~mm}$ diameter and $22 \mathrm{~cm}$ working length;

- laser: side firing $1 \mathrm{~mm}$ laser probe.

\section{Surgical procedure}

Under local anesthesia, the patient is placed in a supine position with the neck extended. A soft strap is placed over the forehead for stabilization. The shoulders are gently distracted downward with tape.

Anterior cervical skin is aseptically prepped and draped. C-arm fluoroscope is brought in and with the help of a metallic needle; skin markings are made with marking pen to indicate the midline and the correct surgical level using AP and lateral C-arm fluoroscopy.

$\mathrm{C}$-arm fluoroscopy is used in anteroposterior and lateral planes to direct the placement of a spinal needle onto the disc space. Usually, a right-sided midline approach is preferred for an intracanalicular disc and a contralateral paramedian approach ( $5 \mathrm{~mm}$ from midline) for a foraminal disc herniation. Initially, at the entry point adjacent to the medial border of the right sternocleidomastoid muscle, local anesthesia (1-2 cc Lidocaine ${ }^{\circledR} 1 \%$ ) is injected and firm pressure is applied digitally in the space between the muscle and the trachea and pointed toward the vertebral surface. Feel the pulse of the carotid artery. Gently, using the tip of your second, third and fourth fingers, the larynx and trachea are displaced medially and the carotid artery, laterally. The anterior cervical spine is palpated with the fingertips and a 18-gauge spinal needle is passed into the center of the disc space while confirmed by fluoroscopic (Figure 2).

Once inside the center of the disc, the stylet is withdrawn and discography is performed by injecting $1 \mathrm{~mL}$ of a mixture (2:1:2 ratio) of radio opaque dye (Telebrix ${ }^{\circledR}$, Guerbert, France), indigo carmine (Carmine $^{\circledR}$, Korean United Pharma, Seoul, South Korea) and normal saline is performed to confirm the intradiscal positioning and to stain the nucleus and herniated fragment to achieve contrast with the adjacent tissues (Figure 3).
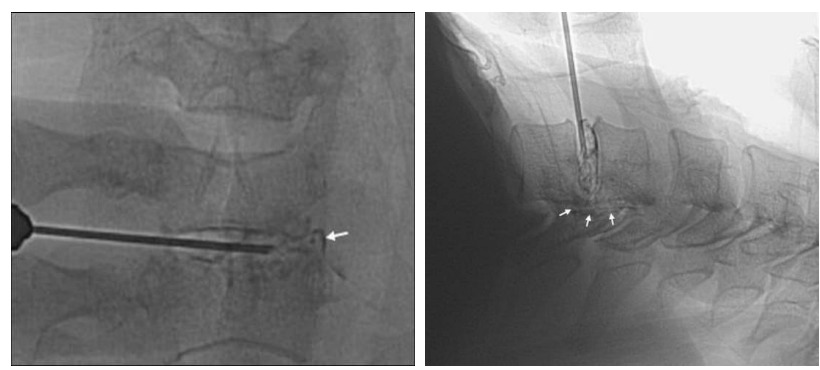

Figure 3

Discography demonstrating stained nucleus and herniated fragment to achieve contrast with the adjacent tissues. (A) AP; (B) lateral

Under fluoroscopic guidance, a narrow guide wire is passed through the needle. The needle is then removed. A 5-mm-skin incision is made to allow the passage of progressive dilators (2 to $5 \mathrm{~mm}$ ) among the guide wire to retract the soft tissues. A trephine inserted through the cannula cuts the annulus in a circular fashion. Finally, a 5-mm-working cannula is inserted into the disc space until it gets to the posterior margin of the disc. The adequate position is verified by fluoroscopic imaging (Figure 4). 

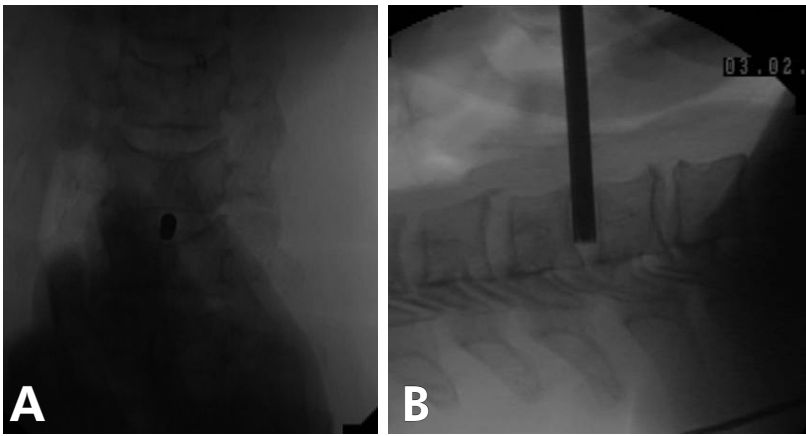

Figure 4

Adequate working channel position verified by fluoroscopic imaging. (A) $A P$; (B) lateral

After adequate positioning and verification, an endoscope with suction-irrigation system is inserted through the working cannula.

Loose fragments seen on entrance should be removed with microforceps. Careful dissection with the holmium: yttrium-aluminum-garnet laser (Ho:YAG) with side-fire probe making movements in a critical fan sweep maneuver must be done until reach the edge of the posterior margin and have visualization of the herniated fragment. Endoscopic side-firing Ho:YAG laser release the annular trap of the herniated fragments from adhesive anchorage in the annulus. Continue monitoring of the working position must be checked with the fluoroscope. After the visualization of herniated fragment, the next step is excised with the help of microforceps. Endoscopic vision helps to confirm the adequacy of the decompression of the dural sac or the exiting root (Figure 5). All working instruments are removed and a single stitch is performed with a compressive bandage. A soft cervical brace is used after the procedure for no more than two weeks. The patient is discharged within the next 24 hours after surgery.

\section{DISCUSSION}

Between March 1993 and August 2004, 1,312 patients were submitted to PECD in our institution, 116 patients were available for revaluation with more than two years of follow-up. This series of patients consisted of 62 men and 54 women with a mean age of 44.8 years (range 21 to 66 years). The patients complained of neck pain or cervicobrachialgia for 7.7 months on average (range 0.5 to 60 months) before PECD. The pain intensity was measured using the Visual Analog Scale (VAS) ${ }^{13}$, the clinical outcome was evaluated according the McNab criteria ${ }^{15}$.

Central disc herniations were found in 28 patients (24.1\%), paracentral in 33 cases (28.4\%) and foraminal in $55(47.5 \%)$. The mean operative time was $56.4 \pm 16.3$ minutes (range: 30 to 140 minutes) and the mean hospital admission was 1.2 days (range: 0 to 10 days). The mean VAS scores for radiculopathy and neck pain decreased from 6.4 to 3.1 and 8.8 to 2.8 , respectively. According to the $\mathrm{McNab}$ criteria, the surgical outcomes were excellent in 60 patients $(51.7 \%)$, good in $41(35 \%)$, fair in $7(6.0 \%)$, and poor in $8(6,9 \%)$, thereby indicating an $87.1 \%$ favorable outcome rate ${ }^{13}$.

Six patients required revision surgeries during the follow-up period. During this proceeding, five patients, who did not have any improvement immediately after PECD, were submitted to anterior discectomy and fusion. The remaining patient underwent bryan cervical disc replacement within five months after PECD ${ }^{13}$.

Some patients experienced transient dysesthesias immediately after PECD, which subsided within two weeks after discharge. In this work, there was no vascular injury, neurologic deterioration, dysphagia, dysphonia or infection.

In our institution, Ahn et al. ${ }^{12}$ retrospectively reviewed the clinical and radiographic records of 36 consecutive patients who underwent PECD from March 2002 to February
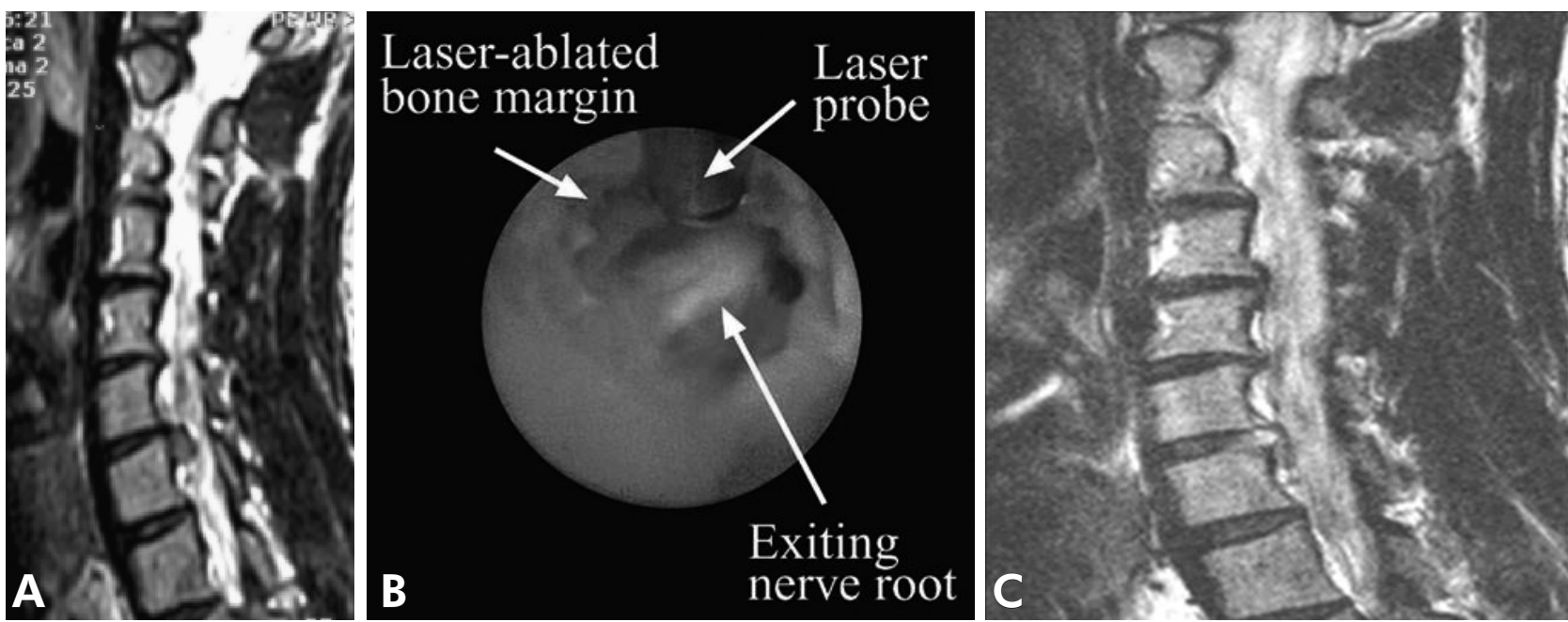

Figure 5

(A) Preoperative MRI; (B) endoscopic view of the nerve decompression and (C) postoperative MRI 
2003. The mean follow-up was 28.6 months (range: 23 to 34 months ). The mean disc height reduction was of $0,8 \mathrm{~mm}$, which represented $10.3 \%$ of the original height. There was no statistical significant difference between the pre and postoperative follow-up of the cervical lordosis or the treated segment focal lordosis. The authors did not find any correlation between lost of disc height and an unfavorable outcome.

Ruetten et al. ${ }^{5}$ compared full-endoscopic anterior decompression (FACD) and anterior decompression and fusion (ACDF) in 120 patients. There was no significant statistical difference in the clinical outcome. Postoperatively, $85.9 \%$ of the patients did not report axial pain or radiculopathy, $10.1 \%$ had occasional axial pain. There was no significant statistical difference concerning adjacent disc degeneration (18.3\% ACDF and 5.9\% FACD), kyphosis angle in the operated segment (8.3\% ACDF and $11.8 \%$ FACD). There was significant statistical difference concerning height of the intervertebral space (ACDF: 6.1 to $5.0 \mathrm{~mm}$ and FACD: 5.3 to $4.1 \mathrm{~mm}$ ). The authors did not find relation between kyphosis, height of the intervertebral space and the clinical outcome. Seven patients out of 103 underwent revision due to persistent arm pain, recurrences or failure of the implant (three patients with previous ACDF and four FACD).

\section{CONCLUSION}

PECD using a Ho:YAG laser and microforceps is a safe and efficacious surgical procedure in the treatment of soft cervical disc herniation.

\section{REFERÊNCIAS}

1. Choi G, Lee S. Percutaneous endoscopic cervical discectomy. In: Korean Spinal Neurosurgery Society, editor. The textbook of spine. Seoul: Koonja Press; 2008. p.1173-85.

2. Ahn Y, Lee SH, Lee SC, Shin SW, Chung SE. Factors predicting excellent outcome of percutaneous cervical discectomy: analysis of 111 consecutive cases. Neuroradiology. 2004;46(5):378-84.

3. Thongtrangan I, Le H, Park J, Kim DH. Minimally invasive spinal surgery: a historical perspective. Neurosurg Focus. 2004;16(1):E13.

4. Chiu JC, Clifford TJ, Greenspan M, Richley RC, Lohman G, Sison RB. Percutaneous microdecompressive endoscopic cervical discectomy with laser thermodiskoplasty. Mt Sinai J Med. 2000;67(4):278-82.

5. Ruetten S, Komp M, Merk H, Godolias G. Full-endoscopic anterior decompression versus conventional anterior decompression and fusion in cervical disc herniations. Int Orthop. 2008 Nov 18. [Epub ahead of print].

6. Bonaldi G, Minonzio G, Belloni G, Dorizzi A, Fachinetti P, Marra A, et al. Percutaneous cervical diskectomy: preliminary experience. Neuroradiology. 1994;36(6):483-6.
7. Tajima T, Sakamoto H, Yamakawa H. Diskectomy cervicale percutanee. Rev Med Orthop. 1989;17:7-10

8. Hoogland T, Scheckenbach C. Lowdose chemonucleolysis combined with percutaneous nucleotomy in herniated cervical disks. J Spinal Disord. 1995;8(3):228-32.

9. Richaud J, Lazorthes Y, Verdie JC, Bonafe A. Chemonucleolysis for herniated cervical disc. Acta Neurochir (Wien). 1988;91(3-4):116-9.

10.Courtheoux F, Theron J. Automated percutaneous nucleotomy in the treatment of cervicobrachial neuralgia due to disc herniation. J Neuroradiol. 1992;19(3):211-6.

11.Ahn Y, Lee SH, Chung SE, Park HS, Shin SW. Percutaneous endoscopic cervical discectomy for discogenic cervical headache due to soft disc herniation. Neuroradiology. 2005;47(12):924-30.

12.Ahn Y, Lee SH, Shin SW. Percutaneous endoscopic cervical discectomy: clinical outcome and radiographic changes. Photomed Laser Surg. 2005;23(4):362-8.
13.Lee SH, Lee JH, Choi WC, Jung B, Mehta R. Anterior minimally invasive approaches for the cervical spine. Orthop Clin North Am. 2007;38(3):327-37; abstract v.

14.Knight MT, Goswami A, Patko JT. Cervical percutaneous laser disc decompression: preliminary results of an ongoing prospective outcome study. J Clin Laser Med Surg. 2001;19(1):38. Comment in: J Clin Laser Med Surg. 2001;19(1):1-2.

15.Macnab I. Negative disc exploration. An analysis of the causes of nerve-root involvement in sixty-eight patients. J Bone Joint Surg Am. 1971;53(5):891903.

\begin{tabular}{l}
\hline Correspondence \\
Gun Choi \\
Wooridul Hospital, 47-4 Cheongdam- \\
dong, Gangnam-gu \\
Seoul, 135-100, South Korea \\
Phone: 82-2-513-8471 \\
Fax: 82-2-513-8146 \\
E-mail: carvalhomax@hotmail.com
\end{tabular}

